\title{
Blended Ag nanofluids with optimized optical properties to regulate the performance of $\mathrm{PV} / \mathrm{T}$ systems
}

\author{
Chunxiao Zhang ${ }^{1,2}$, Chao Shen ${ }^{1,2 *}$, Qianru Yang ${ }^{1}$, Shen Wei ${ }^{3}$, Cheng Sun ${ }^{1}$ \\ ${ }^{1}$ School of Architecture, Harbin Institute of Technology, Key Laboratory of Cold Region Urban and \\ Rural Human Settlement Environment Science and Technology, Ministry of Industry and Information \\ Technology, Harbin 150090, China \\ ${ }^{2}$ State Key Lab of Subtropical Building Science, South China University of Technology, Guangzhou, \\ 510640, China \\ ${ }^{3}$ The Bartlett School of Construction and Project Management, University College London (UCL), \\ London, WC1E 7HB, UK \\ Corresponding author: Chao Shen, chaoshen@hit.edu.cn
}

Abstract: Traditional PV/T systems, with passive cooling channels, can not solve the problem of coupling power/heat source on the surface of PV modules, resulting in lower electrical efficiency of solar cells. The active spectrum regulation technology using nanofluids, is a promising method to absorb spectrum energy not responding to solar cells, and reduce cell temperature and improve electricity efficiency. Though many nanofluids have been selected as optical nanofluids to separate/decoupling electricity and heat from composite spectral energy, no feasible method was proposed to select proper nanofluids to match the ideal window of solar cells. Therefore, from the view of spectrum regulation, some blended Ag nanofluids were present to numerically investigate the performance of PV/T systems, using a 2D-Monte Carlo method. Results indicated that nanoparticle radius, ranging from $20 \mathrm{~nm}$ to $60 \mathrm{~nm}$, drove the movement of peak absorption from $395 \mathrm{~nm}$ to $520 \mathrm{~nm}$, following a linear profile. Meanwhile, increased volume concentration and optical thickness reduced spectral transmittance, leading to lower cell temperature but worse output performance. Additionally, blended Ag nanofluids, with particle radius of $20 \mathrm{~nm}$ or $20 / 40 \mathrm{~nm}(8: 2)$, volume concentration of $2.5 \mathrm{ppm}$ and optical path of $10 \mathrm{~mm}$, were optimal solutions for both Si cell and GaAs cell. The electrical efficiency and merit function value of Si cells were $11.85 \%$ and 1.61 for $20 \mathrm{~nm}$ nanofluid, $11.0 \%$ and 1.66 for $20 / 40 \mathrm{~nm}(8: 2)$ nanofluid, while that of GaAs cell were $9.30 \%$ and 1.92 for $20 \mathrm{~nm}$ nanofluid, $9.03 \%$ and 2.05 for $20 / 40 \mathrm{~nm}(8: 2)$ nanofluid, respectively.

Keywords: Blended nanofluids, Monte Carlo method, Spectrum regulation, Merit function 
$\boldsymbol{A} \quad$ Heat transfer area, $\left(\mathrm{m}^{2}\right)$

C Solar concentration ratio, (dimensionless)

D Diameter of nanoparticles, $(\mathrm{nm})$

$\boldsymbol{e} \quad$ Electron charge, $\left(1.6021 \times 10^{-19} \mathrm{C}\right)$

Fill factor, (dimensionless)

$\boldsymbol{f}_{\boldsymbol{v}, \boldsymbol{i}} \quad$ Nanoparticle volume percentage with diameter $\boldsymbol{D}$, (dimensionless)

Isc Short circuit current, $(\mathrm{mA})$

The spectral blackbody radiation, $\left(\mathrm{W} \cdot \mathrm{m}^{-2} \cdot \mathrm{nm}^{-1}\right)$

Incident solar radiation, $\left(\mathrm{W} \cdot \mathrm{m}^{-2} \cdot \mathrm{nm}^{-1}\right)$

$\boldsymbol{K}_{\text {ext }}$ Extinction coefficient of nanofluids, $\left(\mathrm{cm}^{-1}\right)$

Absorption coefficient of nanofluids, $\left(\mathrm{cm}^{-1}\right)$

Extinction coefficient of nanoparticle systems, $\left(\mathrm{cm}^{-1}\right)$

Absorption coefficient of nanoparticle systems, $\left(\mathrm{cm}^{-1}\right)$

Extinction coefficient of base fluid, $\left(\mathrm{cm}^{-1}\right)$

Absorption coefficient of base fluid, $\left(\mathrm{cm}^{-1}\right)$

Boltzmann constant, $\left(1.38 \times 10^{-23} \mathrm{~J} / \mathrm{K}\right)$

Merit function of PV/T systems, (dimensionless)

Relative complex refraction index, (dimensionless)

$\boldsymbol{n}_{\boldsymbol{f}} \quad$ Refraction index of base fluid, (dimensionless)

Optical thickness, (cm) 
$60 \quad \boldsymbol{T}_{\boldsymbol{a}} \quad$ Ambient temperature, (K)

$61 \boldsymbol{T}_{\text {cell }} \quad$ Cell temperature, $(\mathrm{K})$

$62 \boldsymbol{T}_{\text {cell }}^{\prime} \quad$ Reference cell temperature, (298K)

$63 \boldsymbol{T}_{\text {sky }} \quad$ Sky temperature, $(\mathrm{K})$

$64 \quad V_{o c} \quad$ Open circuit voltage, (V)

$65 V_{o c}^{\prime} \quad$ Open circuit voltage at cell temperature of $289 \mathrm{~K},(\mathrm{~V})$

$66 x \quad$ Size parameter of nanoparticles, (dimensionless)

$67 \boldsymbol{x}_{\boldsymbol{r}} \quad$ Relative size parameter, (dimensionless)

68 Greek symbol

$69 \boldsymbol{\beta} \quad$ Coefficient, $\left(0.0045 \mathrm{~K}^{-1}\right)$

$70 \boldsymbol{\varepsilon} \quad$ Surface emissivity of object, (dimensionless)

$71 \eta_{\boldsymbol{e l}} \quad$ Electrical efficiency, (dimensionless)

$72 \boldsymbol{\theta} \quad$ Scattering angle, (radian)

$73 \lambda \quad$ Incident wavelength, (nm)

$74 \sigma \quad$ The constant of Stefan and Bohzmann, $\left(5.67 \times 10^{-8} \mathrm{~W} \cdot \mathrm{m}^{-2} \cdot \mathrm{K}^{-4}\right)$

$\begin{array}{llll}75 & \boldsymbol{\tau}_{\lambda} & \text { Spectral transmittance, (dimensionless) }\end{array}$

$76 \boldsymbol{\Phi}_{\lambda} \quad$ The spectral scattering phase function, (dimensionless)

$77 \boldsymbol{\Phi}(\boldsymbol{\theta}) \quad$ Scattering phase function of nanoparticle systems, (dimensionless)

$\begin{array}{lll}78 & \mathbf{\Omega} & \text { The solid angle, (radian) }\end{array}$

$79 \boldsymbol{\omega} \quad$ Albedo of single nanoparticle, (dimensionless) 


\section{Introduction}

With the increase of world population and the aggravation of energy crisis, most countries have devoted themselves to utilizing renewable energy (Shen et al., 2020; Wei et al., 2020). As a sustainable and environment-friendly energy, solar energy has advantages like large reserves, wide distribution and no pollution (Zhang et al., 2020b), and therefore has captured great attentions of researchers and developers (Yao et al., 2020).

After years of development, solar technologies, such as PV panels, solar collectors and passive solar energy utilization, have entered thousands of buildings (Ghosh et al., 2019; Sahin et al., 2020). For commercial applications, PV panels are widely used and each panel is composed of a number of solar cells that can convert solar energy into electricity. The efficiency of solar cells, however, is generally low (less than 25\%), due to their spectral response characteristics (Green et al., 2015), i.e. they can only convert solar energy within specific spectral ranges (generally within 300nm-1100nm). Meanwhile, the volt-ampere characteristic curve of PV modules is also subject to cell temperature, with a decreasing rate of electrical efficiency by about $0.5 \% /{ }^{\circ} \mathrm{C}$ at high temperature (Zhang et al., 2020a). To tackle this issue, many researchers have proposed feasible measures to reduce cell temperature, so as to maintain certain electrical efficiency of PV modules.

To cool down PV modules, universal cooling methods include air cooling, water cooling, phase change material cooling and structure strengthening cooling have been proposed in recent years (Al-Waeli et al., 2018; Ali, 2020). These cooling methods can effectively reduce cell temperature by $5^{\circ} \mathrm{C}-40^{\circ} \mathrm{C}$ for flatbed PV modules, and improve electrical efficiency by about 0.5\%-10\% (Al-Waeli et al., 2018; Hasan et al., 2010). Muneeshwaran et al. investigated the cooling performance of PV modules with an air-cooling system, and results indicated that cell temperature with cooling channel was lower than that without cooling channel by $6^{\circ} \mathrm{C}-12^{\circ} \mathrm{C}$ (Muneeshwaran et al., 2020). Hafz Muhammad Ali reviewed the recent advancements in PV cooling, and demonstrated the PCM cooling was a feasible solution to maintain cell temperature within stable range (Ali, 2020). Meanwhile, they hold that PCMs integrated with nanoparticles can significantly improve the thermal conductivity, and then enhance cooling efficiency (Tariq et al., 2020). Among these cooling technologies, nanofluids, with superior heat exchanged capacity, have been studied in recent years (Menni et al., 2018; Younes Menni et al., 2019b). Zhang et al. reviewed 
the cooling technologies of PV modules, including fluid medium cooling, structural configuration cooling and PCMs cooling, and they reported that nanofluids cooling can be regarded as a preferred cooling method, due to efficient heat transfer ability (Zhang et al., 2020a). Research group of Professor Menni has carried out a large number of studies, from the view of enhanced heat transfer of nanofluids (Menni et al., 2020; Menni et al., 2019b). They have proved that the physical properties, particle size, concentration and flow rate of nanofluids were key factors to enhance the heat transfer of fluids (Younes Menni et al., 2019b). Meanwhile, some novel channels with baffle structure also have been designed by their group to improve cooling efficiency (Menni et al., 2019a; Younes Menni et al., 2019a).

Universal cooling methods try to take excessive heat away from PV modules but cannot limit unuseful solar energy touching solar cells. In this research direction, Taylor firstly used the spectral regulation technology by nanofluids to filter sunlight unuseful to solar cells, to obtain lower cell temperature (Hjerrild and Taylor, 2017; Taylor et al., 2012). Since then, some researchers have provided contributions to this research direction (DeJarnette et al., 2016; Han et al., 2019a; Hassani et al., 2016). Han et al. investigated the performance of solar cells using $\mathrm{CoSO}_{4}$-based $\mathrm{Ag}$ nanofluids as optical filter, and results demonstrated that the electrical efficiency of solar cells is dependent on the mass fraction of optical nanofluids (Han et al., 2019a). DeJarnette et al. proposed a nanofluid mixing with Au and indium tin oxide nanoparticles, and analysed the optical properties of this blended nanofluid. From experiment, they have discovered that the filter efficiency of this nanofluid was $56 \%$ for Si cells and $62 \%$ for GaAs cells (DeJarnette et al., 2016). Hassani et al. investigated the difference between optical nanofluids and thermal nanofluids, and theoretically discussed the electrical efficiency of solar cells with channels filled with different nanofluids (Hassani et al., 2016). They also suggested to use optical nanofluids above solar cells and use thermal nanofluids below solar cells. Additionally, using these two different nanofluids simultaneously can also provide a better performance than using them separately.

In reality, solar cells made by different materials, such as $\mathrm{Si}$ and GaAs, have different spectral response characteristics (Han et al., 2019b) as shown in Figure 1, which were measured for Si cells and GaAs cells with AM1.5 standard spectrum. Apparently, Si cells had an ideal PV windows ranging between 700nm to $1100 \mathrm{~nm}$, and GaAs cells had one ranging between $700 \mathrm{~nm}$ and $900 \mathrm{~nm}$. Each nanofluid has unique absorption spectrum, but not every nanofluid is suitable as an optical filter for solar cells. Therefore, how to efficiently filter unuseful solar energy with proper nanofluids for different solar cells? It is a very 
meaningful topic. Although many researches have investigated the optical properties of nanofluids, and discussed the performance of PV/T systems with selective nanofluids. In existing studies, however, no method was available to guide how to select proper nanofluids for different solar cells. This study, therefore, reported some blended $\mathrm{Ag}$ nanofluids for solar cells from the view of spectrum regulation, and investigated the effects of volume concentration and optical thickness on the spectral absorption characteristics of nanofluids, using a two-dimensional Monte Carlo method. Additionally, the study established a link between these characteristics and requirements of solar cells. Several feasible solutions were proposed for two typical solar cells, namely Si cells and GaAs cells. The results from this project can provide reference for the future development of solar spectral regulation technologies and promote efficient utilization of solar energy.

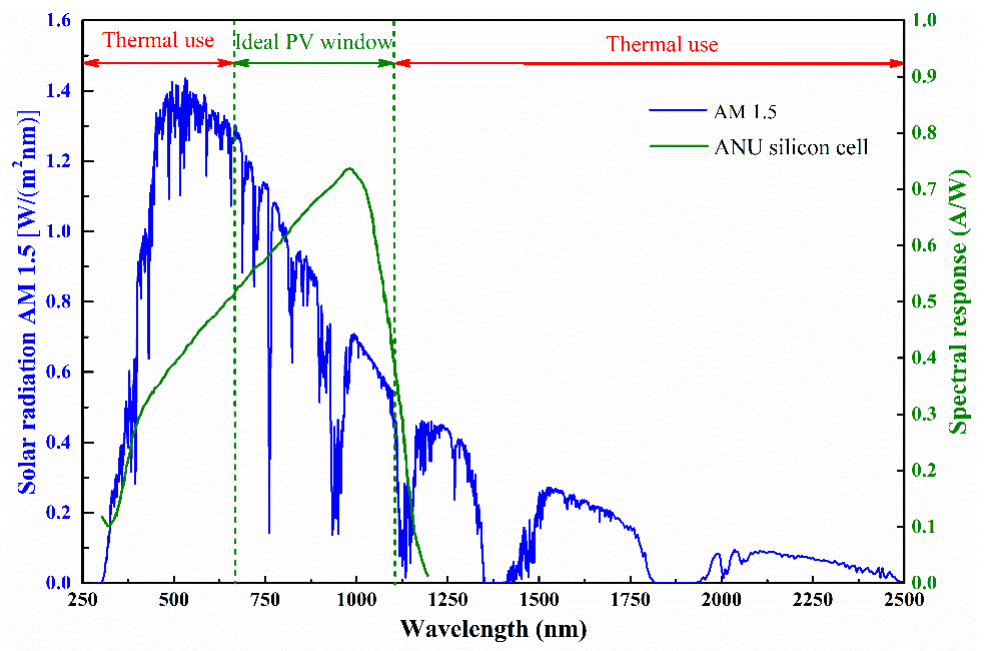

(a) Ideal window (700nm-1100nm) of Si cell tested by the Australian National University (ANU)

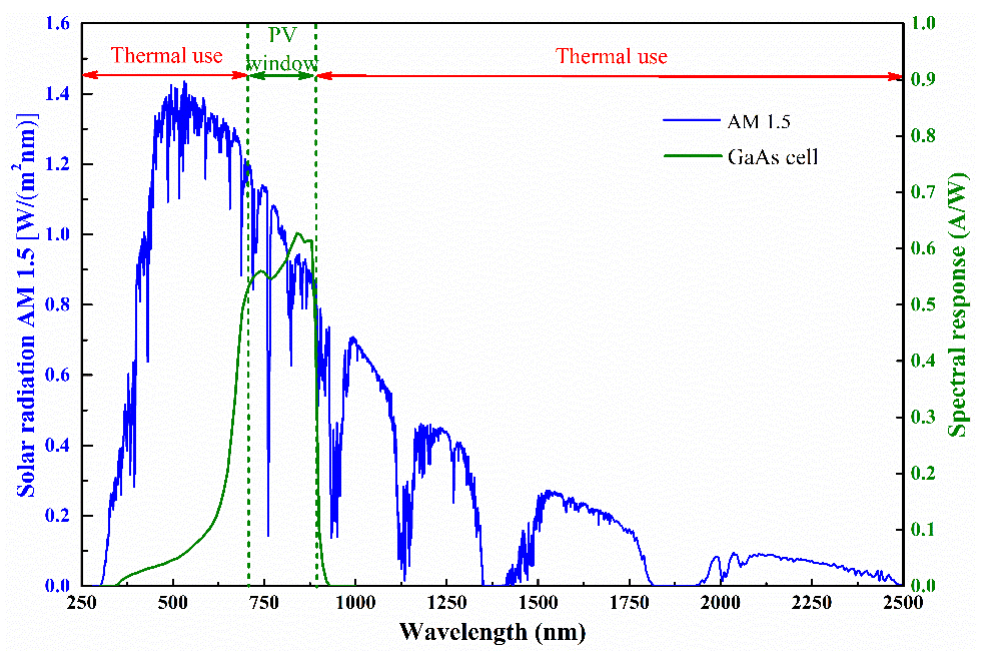

(b) Ideal window of GaAs cell (700nm-900nm) 


\section{Model Development}

Figure 2 depicted the flow chart of current study. Before discussing the spectrum matching of nanofluids with solar cells, theoretical investigation of optical characteristics of nanofluids should be detailedly depicted. Nanofluids are mainly composed of nanoparticles and base fluid, which directly determine optical properties of nanofluids. First, Mie theory was adopted to get radiative characteristic of single nanoparticle, and then optical characteristic of nanofluids was calculated by independent scattering theory of nanoparticles systems. After that, a 2D-Monte Carlo method was employed to solve radiation transfer equation and obtain spectral transmittance of nanofluids, and the results was validated with existing literature. Then, the effect of these factors, including nanoparticles radius, refractive index of base fluids, volume concentration and optical thickness, on the spectral transmittance were investigated to match the ideal windows of solar cells. Finally, the performance of PV/T systems with optimized blended Ag nanofluids was also discussed by some mathematical models of PV/T systems.

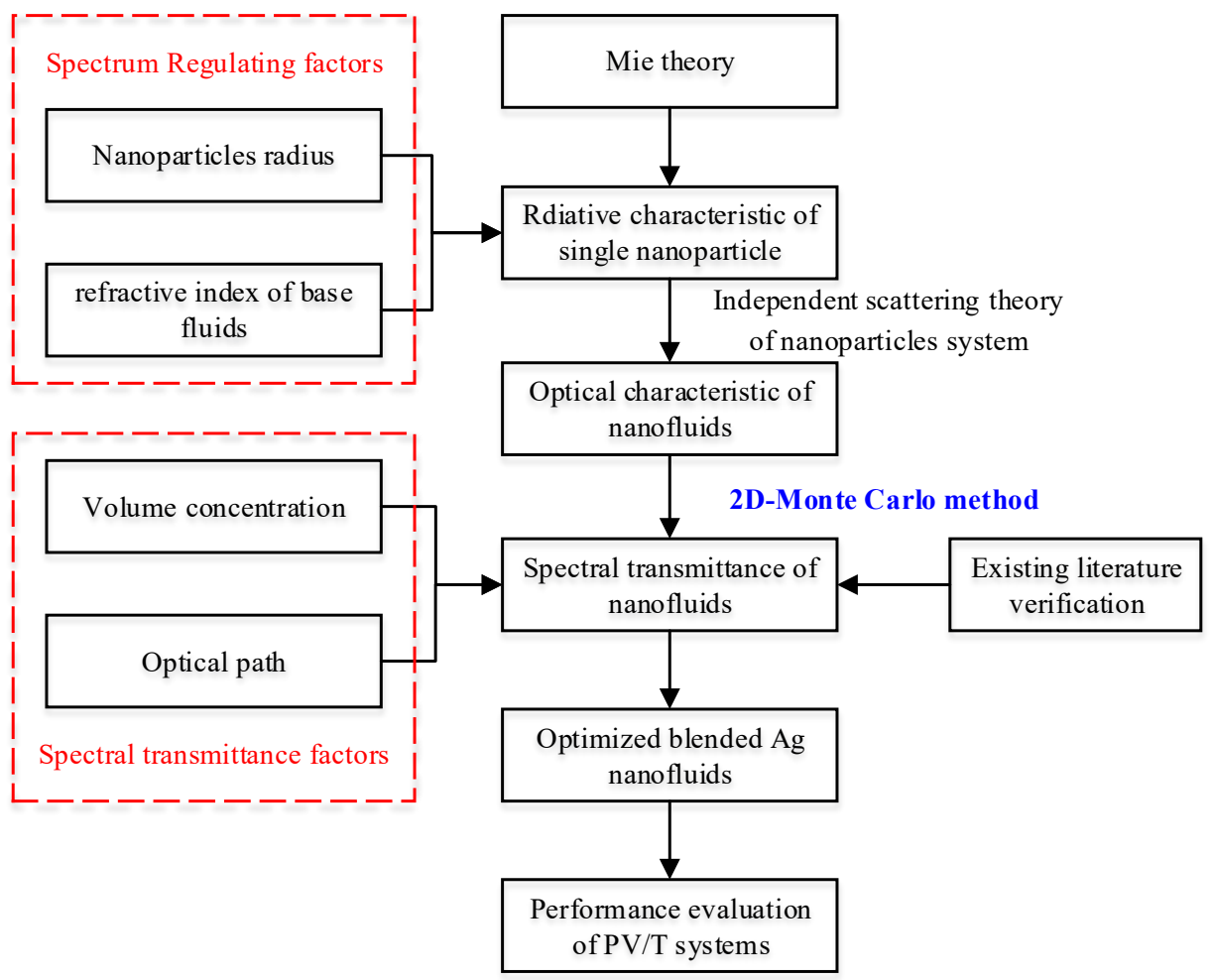

Figure 2: Flow chart of current study

\subsection{Radiative characteristic of single nanoparticle}

Currently, there are many existing methods that can be used to obtain the radiation characteristics of 
single nanoparticle, including Mie theory (Xingcai and Kun, 2018), discrete dipole approximation (Zhang et al., 2019), finite difference method (Wriedt, 2009) and T-matrix (Hellmers and Wriedt, 2013) method. The Mie theory is most appropriate solution to get the radiation characteristics of isotropic spherical particles, not approximate solution, which has been demonstrated in many studies (Xingcai and Kun, 2018). Therefore, the Mie theory was adopted to obtain extinction factor, absorption factor, scattering factor and scattering phase function of spherical nanoparticles in this research, as described in Section 2.1. Then, according to the independent scattering theory and radiation characteristics of basic fluid (consulted from reference (Tan et al., 2017)), the optical characteristics of nanofluids were obtained, including extinction coefficient, absorption coefficient, scattering coefficient and scattering phase function, as described in Section 2.2. Afterwards, in Section 2.3, a two-dimensional Monte Carlo method was proposed to solve the radiation transfer equation of nanofluids in cuvette, using MATLAB.

Using Mie theory, four dimensionless variables, including the extinction factor $\left(\boldsymbol{Q}_{e x t}\right)$, the absorption factor $\left(\boldsymbol{Q}_{a b s}\right)$, the scattering factor $\left(\boldsymbol{Q}_{s c a}\right)$ and the albedo $(\boldsymbol{\omega})$ of the particles, could be obtained by the Lorenz-Mie electromagnetic theory. The extinction factor is the sum of absorption factor and the scattering factor, and albedo of the particles is the rate of scattering factor to extinction factor.

$$
\begin{aligned}
& Q_{\text {ext }}=\frac{2}{x^{2}} \operatorname{Re}\left[\sum_{n=1}^{\infty}(2 n+1)\left(a_{n}+b_{n}\right)\right] \\
& Q_{\text {sca }}=\frac{2}{x^{2}} \sum_{n=1}^{\infty}(2 n+1)\left(\left|a_{n}\right|^{2}+\left|b_{n}\right|^{2}\right)
\end{aligned}
$$

$$
\begin{gathered}
Q_{a b s}=Q_{e x t}-Q_{s c a} \\
\omega=Q_{s c a} / Q_{e x t} \\
x=\pi D / \lambda
\end{gathered}
$$

Where $\boldsymbol{R} \boldsymbol{e}$ is the real part of complex number (dimensionless); $\boldsymbol{D}$ is the diameter of nanoparticles (nm); $\lambda$ is the incident wavelength (nm); $\boldsymbol{x}$ is size parameter of nanoparticles (dimensionless); $\boldsymbol{a}_{\boldsymbol{n}}$ and $\boldsymbol{b}_{\boldsymbol{n}}$ are the scattering coefficients of theory (dimensionless). $\boldsymbol{a}_{\boldsymbol{n}}$ and $\boldsymbol{b}_{\boldsymbol{n}}$ can be calculated by Equation 6 and Equation 7, respectively, 
where $\xi_{n}=\psi_{n}+i \chi_{n}$, and $\psi_{n}, \quad \chi_{n}$ are Ricatti-Bessel function, coincided with Equations 8 and 9.

195

$$
\begin{aligned}
& \psi_{n+1}(x)=\frac{2 n+1}{x} \psi_{n}(x)-\psi_{n-1}(x) \\
& \chi_{n+1}(x)=\frac{2 n+1}{x} \chi_{n}(x)-\chi_{n-1}(x) \\
& \psi_{-1}(x)=\cos x ; \quad \psi_{0}(x)=\sin x \\
& \chi_{-1}(x)=-\sin x ; \quad \chi_{0}(x)=\cos x
\end{aligned}
$$

The Scattering phase function is a vital parameter for solving the radiation transfer equation, and can be obtain by the following equations,

$$
\Phi_{p}(\theta)=\frac{2\left(i_{1}+i_{2}\right)}{x^{2} Q_{s c a}}
$$

$$
i_{1}(\theta)=\left|S_{1}\right|^{2} ; \quad i_{2}(\theta)=\left|S_{2}\right|^{2}
$$

$$
S_{1}(\theta)=\sum_{n=1}^{\infty} \frac{2 n+1}{n(n+1)}\left[a_{n} \pi_{n}(\cos \theta)+b_{n} \tau_{n}(\cos \theta)\right]
$$$$
S_{2}(\theta)=\sum_{n=1}^{\infty} \frac{2 n+1}{n(n+1)}\left[a_{n} \tau_{n}(\cos \theta)+b_{n} \pi_{n}(\cos \theta)\right]
$$

$$
\pi_{n}(\cos \theta)=\frac{d P_{n}(\cos \theta)}{d \cos \theta}
$$

$$
\tau_{n}(\cos \theta)=\frac{d P_{n}(\cos \theta)}{d \cos \theta} \cos \theta-\frac{d^{2} P_{n}(\cos \theta)}{d \cos ^{2} \theta} \sin ^{2} \theta
$$

where $\boldsymbol{\theta}$ is scattering angle (radian); $\boldsymbol{i}_{1}$ and $\boldsymbol{i}_{2}$ are non-dimensional polarized intensities; $\boldsymbol{S}_{1}$ and $\boldsymbol{S}_{2}$ are complex amplitude functions and directionally dependent function (dimensionless); $\boldsymbol{P}_{\boldsymbol{n}}$ is the Legendre polynomial.

If nanoparticles are placed in water or other base fluid, the relative complex refraction index $(\boldsymbol{m} r$, dimensionless) and the relative size parameter ( $\boldsymbol{x}_{\boldsymbol{r}}$, dimensionless) need to be used in the Mie theory, and they could be obtained by Equation 16 and 17,

$$
\begin{aligned}
& m_{r}=\frac{n_{p}-i k_{p}}{n_{f}} \\
& x_{r}=\frac{\pi D n_{f}}{\lambda}
\end{aligned}
$$

where $\boldsymbol{n}_{p}, \boldsymbol{k}_{p}$ and $\boldsymbol{n}_{f}$ are the refraction index of nanoparticle, the absorption index of nanoparticle and the refraction index of base fluid, respectively. 
216 The optical characteristic of nanofluids is generally determined by the radiative characteristics of both 217 base fluid and nanoparticle system. The extinction coefficient and absorption coefficient of nanofluids is 218 calculated by summation those of base fluid and nanoparticle system (as described in Equations 18 and 19), respectively,

where $\boldsymbol{K}_{\text {ext }} \boldsymbol{K}_{\boldsymbol{p} \text {,ext }}$ and $\boldsymbol{K}_{\boldsymbol{f}, \text { ext }}$ are extinction coefficient of nanofluids (in $\mathrm{cm}^{-1}$ ), extinction coefficient of nanoparticle systems (in $\mathrm{cm}^{-1}$ ) and extinction coefficient of base fluid (in $\mathrm{cm}^{-1}$ ), and $\boldsymbol{K}_{\boldsymbol{a b s}} \boldsymbol{K}_{\boldsymbol{p}, \boldsymbol{a b s}}$ and $\boldsymbol{K}_{\boldsymbol{f}, \boldsymbol{a b s}}$ are absorption coefficient of nanofluids (in $\mathrm{cm}^{-1}$ ), absorption coefficient of nanoparticle systems (in $\mathrm{cm}^{-1}$ ) and absorption coefficient of base fluid (in $\mathrm{cm}^{-1}$ ).

Base fluid is often considered as no scattering medium, and therefore has neglectable scattering coefficient. The extinction coefficient of base fluid is actually the absorption coefficient $\left(\boldsymbol{K}_{\boldsymbol{f}, \mathbf{a b s}}, \mathrm{cm}^{-1}\right)$ of base fluid, which could be obtained from related reference (Tan et al., 2017).

The radiative characteristic of nanoparticle system is calculated by radiative characteristic of single 
242

Once the optical characteristic of nanofluids is given, the Monte Carlo method can be used to solve radiation transfer equations (Tan et al., 2017; Yi et al., 2014). The spectral radiation along the path $s$ is affected by extinction effect of nanofluids, absorption effect of spectral blackbody radiation and scattering effect by nanoparticles, as shown in Equation 24,

$$
\frac{d I_{\lambda}(s)}{d s}=-K_{e x t} I_{\lambda}(s)+K_{a b s} I_{b \lambda}(s)+\frac{K_{s c a}}{4 \pi} \int_{4 \pi} I_{\lambda}\left(s, \overrightarrow{\Omega^{\prime}}\right) \Phi_{\lambda}\left(\vec{\Omega}, \overrightarrow{\Omega^{\prime}}\right) d \Omega^{\prime}
$$

where $\boldsymbol{I}_{\boldsymbol{\lambda}}$ is spectral radiation (in $\mathrm{W} \cdot \mathrm{m}^{-2} \cdot \mathrm{nm}^{-1}$ ) along the path $\boldsymbol{s} ; \boldsymbol{I}_{\boldsymbol{b} \boldsymbol{\lambda}}$ is the spectral blackbody radiation (in $\mathrm{W} \cdot \mathrm{m}^{-2} \cdot \mathrm{nm}^{-1}$ ), $\boldsymbol{\Omega}$ is the solid angle (in radian) and $\boldsymbol{\Phi}_{\lambda}$ is the spectral scattering phase function (dimensionless).

The extinction coefficient of nanofluids could be obtained from Section 2.2, and the absorption of spectral blackbody radiation is neglectable at low temperature. According to reference (Tan et al., 2017), the scattering effect among nanoparticles should not be neglected, especially at high albedos. As depicted in Figure 3, the spectral transmittance with an incident wavelength, is the ratio of number of photons reaching detectors to the total number of photons (using $N=10^{9}$ here, according to existing studies (Yi et al., 2014)). When one photon passes through nanofluids, it will be either absorbed or scattered. The free path length (step length $\Delta \boldsymbol{s}$ ) depends on the extinction coefficient of nanofluids, as defined by Equation 25 , where $\xi_{1}$ is a random number between 0 and 1 , following uniform distribution.

$$
\Delta s=-\frac{\ln \left(\xi_{1}\right)}{K_{e x t}}
$$

When a photon reaches the surface of a nanoparticle, another random number $\xi_{2}$ between 0 and 1 (uniform distribution), will also be generated to determine whether that photon will be absorbed or scattered (if $\xi_{2}$ is less than the albedo $(\boldsymbol{\omega})$ of nanoparticles, the photon would be scattered, otherwise it would be absorbed). 


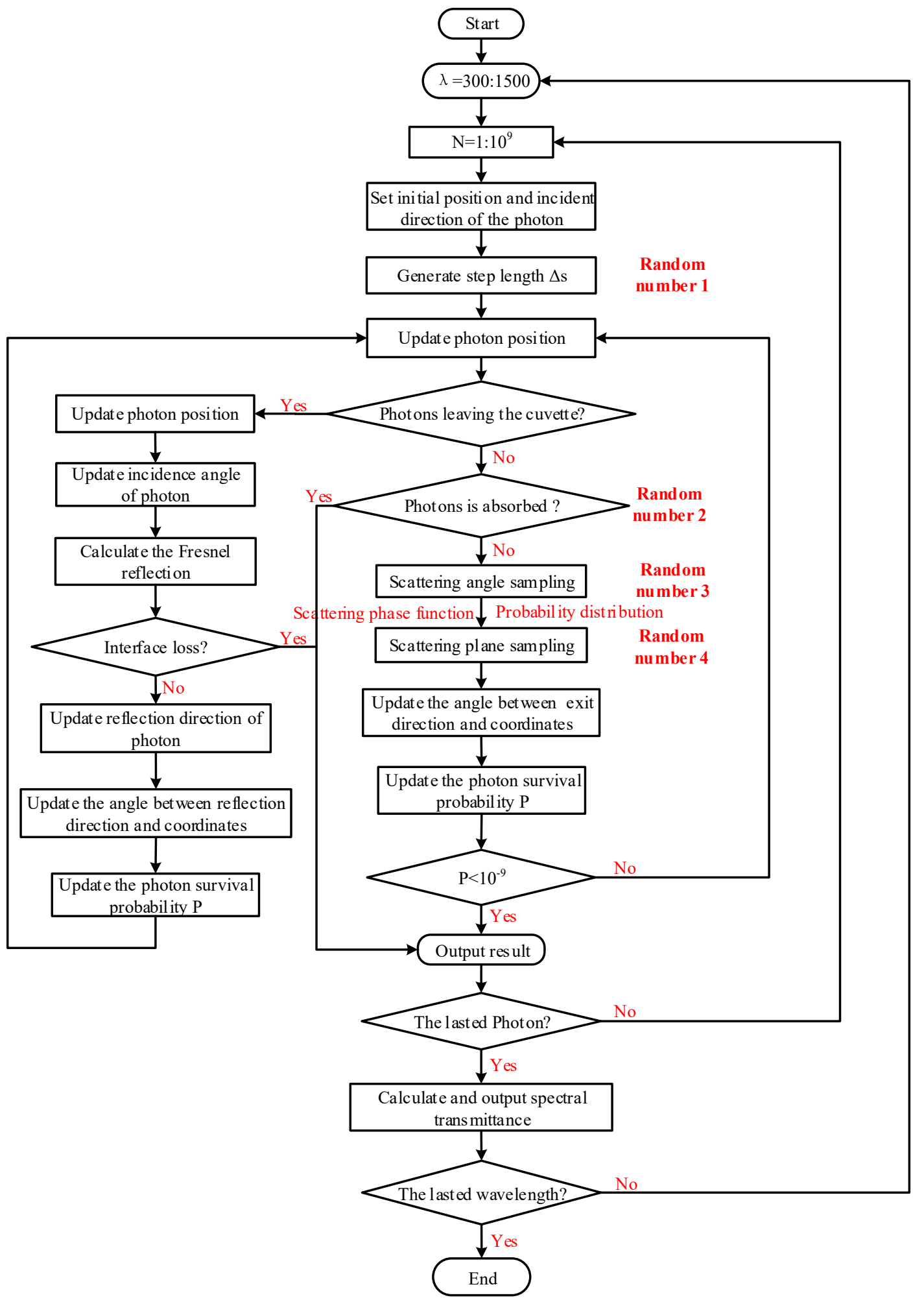

Figure 3: A 2D-Monte Carlo method to estimate spectral transmittance of nanofluids

265 For a three-dimensional Monte Carlo method, if one photon is scattered, two angles $(\boldsymbol{\theta}$ and $\boldsymbol{\varphi})$ would

266 be determined to specify its direction, using another two random number $\left(\xi_{3}\right.$ and $\left.\xi_{4}\right)$ between 0 and 1 ,

267 based on the scattering phase function of nanofluids. According to the definition of scattering phase 
function, is complies with probability density function, ranging between 0 and $\boldsymbol{\pi}$. Once $\xi_{3}$ is confirmed, the scattering angle $\boldsymbol{\theta}$ can be obtained by Equation 26, and the scattering plane angle $\varphi$ is a random value between 0 and $2 \pi$, determined by $\xi_{4}$.

$$
P_{\lambda}(\theta)=\int_{0}^{\theta} \frac{1}{2} \Phi(\theta) \sin (\theta) d \theta=\xi_{3} \quad 0 \leq P_{\lambda}(\theta) \leq 1
$$

The coordinates of photons in 3D Monte Carlo method needs to be updated frequently in the cartesian coordinate system, so as to judge whether they leave the cuvette or not. Therefore, this method is timeconsuming and not very efficient. To simplify the computational procedure, a two-dimensional Monte Carlo method was adopted for calculating the spectral transmittance of nanofluids in cuvette. For a sphere nanoparticle with given scattering angle $(\boldsymbol{\theta})$, the probability of one photon leaving from an arbitrary scattering plane is the same. If $\xi_{4}$ is less than $0.5, \boldsymbol{\theta}$ is a negative value. Otherwise, $\boldsymbol{\theta}$ is a positive value. Then, the position of one photon after each scattering, could be obtained by an iterative calculation of scattering angle $(\boldsymbol{\theta})$ in the two-dimensional plane. Additionally, if the survival probability of a photon $(\boldsymbol{P})$ is less than $10^{-9}$, the photon would not be traced. It should be noted that, Fresnel reflection loss should be considered when a photon arrives at the surface of optical glasses.

\section{Model Validation}

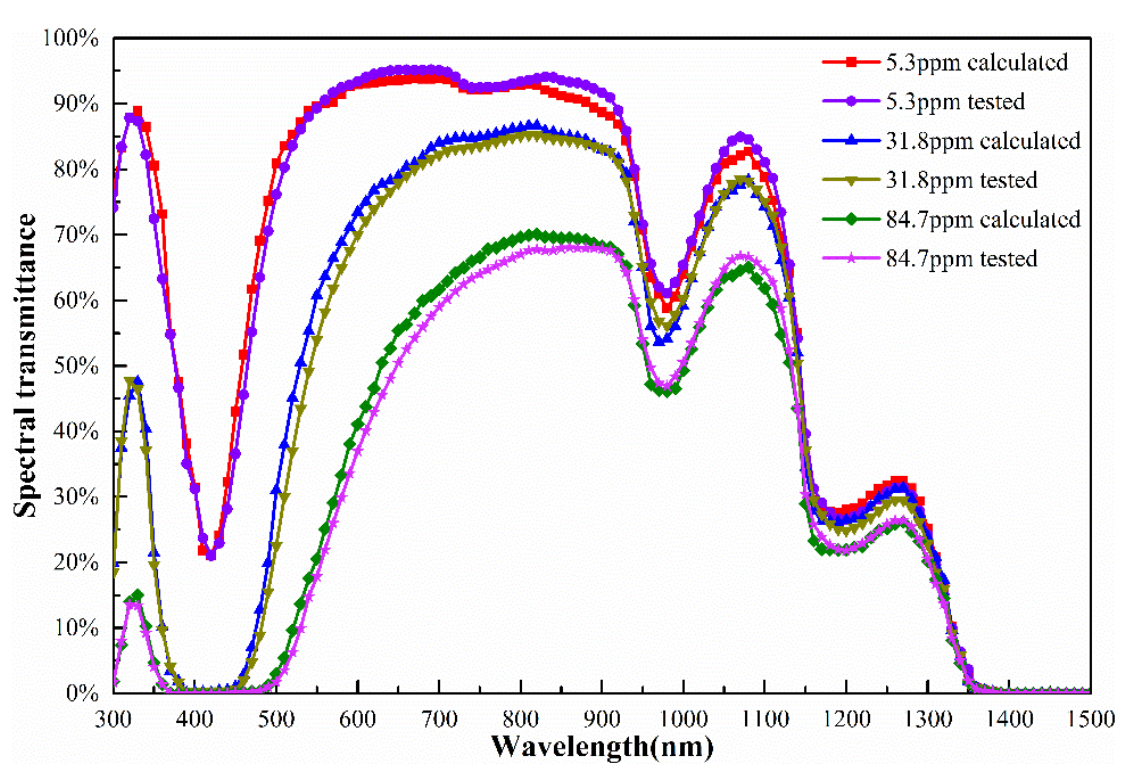

Figure 4: Model validation results for Ag-water nanofluids (Han et al., 2019a)

To verify the feasibility of the 2D-Monte Carlo method developed here, the spectral transmittances of $\mathrm{Ag} /$ water nanofluids with different mass fractions, as proposed by reference (Han et al., 2019a), were 
used. In the validation process, the average radius of silver nanoparticles was set as $25 \mathrm{~nm}$, the refractive index of environment medium was set as 1.33 , and the complex refractive index of wavelengths between $300 \mathrm{~nm}$ and $1500 \mathrm{~nm}$ were obtained from reference (McPeak et al., 2015). Figure 4 depicted the calculated directional-directional spectral transmittances for $10 \mathrm{~mm}$ optical thickness by the 2D-Monte Carlo method, and compared them with the experimental results from reference (Han et al., 2019a). Apparently, a good agreement between them was observed, with mean relative errors of $2.26 \%, 3.20 \%$ and $3.92 \%$, for $5.3 \mathrm{ppm}, 31.8 \mathrm{ppm}$ and $84.7 \mathrm{ppm}$, respectively.

In addition to Ag-water nanofluids, the spectral transmittance of $\mathrm{ZnO}$ nanofluids with high albedo (average diameter of $10 \mathrm{~nm}$, mass fraction of $0.02 \%$ and path thickness of $10 \mathrm{~mm}$ ), was calculated as well, and compared with experimental data available in reference (Zhu et al., 2013). As shown in Figure 5, the calculated values showed a good match with the experimental values, with an average relative error of $2.66 \%$.

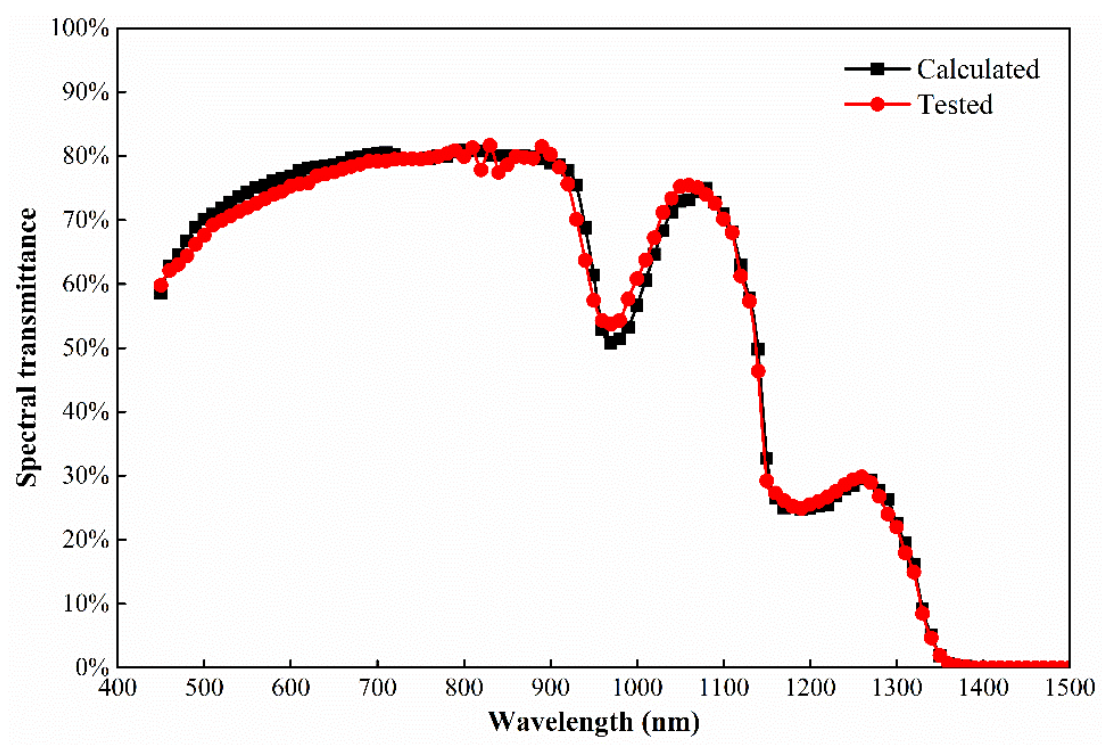

Figure 5: Model validation results for ZnO-water nanofluids (Zhu et al., 2013)

\section{Optical regulating characteristics of nanofluids}

Before discussing the performance of PV/T systems, the optical regulating characteristics of nanofluids should be understood based on two aspects, namely, the radiation characteristics of single nanoparticles and the spectral transmittance of Ag nanofluids, as discussed in Sections 4.1 and 4.2. 
The optical properties of nanofluids are determined by the radiation characteristic of the constituent nanoparticles. Therefore, it is necessary to discuss the radiation characteristic of single nanoparticle, using the method described in Section 2.1.

Due to weak absorption within the infrared region, Figure 6 only depicted the effect of particle radius on the extinction factor of single nanoparticle within the UV-visible region. As incident wavelength increased, the extinction factor increased first and then started to decrease until zero. With the increase of particle size, the absorption peak of nanoparticles gradually started to linearly shift to the infrared region, and the extinction factor at absorption peak decreased, mainly due to the surface plasmon resonance effect influenced by particle size (Félidj et al., 2008), as confirmed in references (Jain et al., 2006; Lee and El-Sayed, 2005; Ren et al., 2017). It is an effective way to solve the problem of directional spectrum absorption for solar cells by regulating particle size of nanoparticles to transfer the absorption peak. Although absorption peak achieved linear migration, the absorption range of particles became wider, which may hinder the suitable spectral transmittance for solar cells. Albedo increased as particle size rose at all wavelength, and this will also affect the transmittance of nanofluids (Tan et al., 2017).

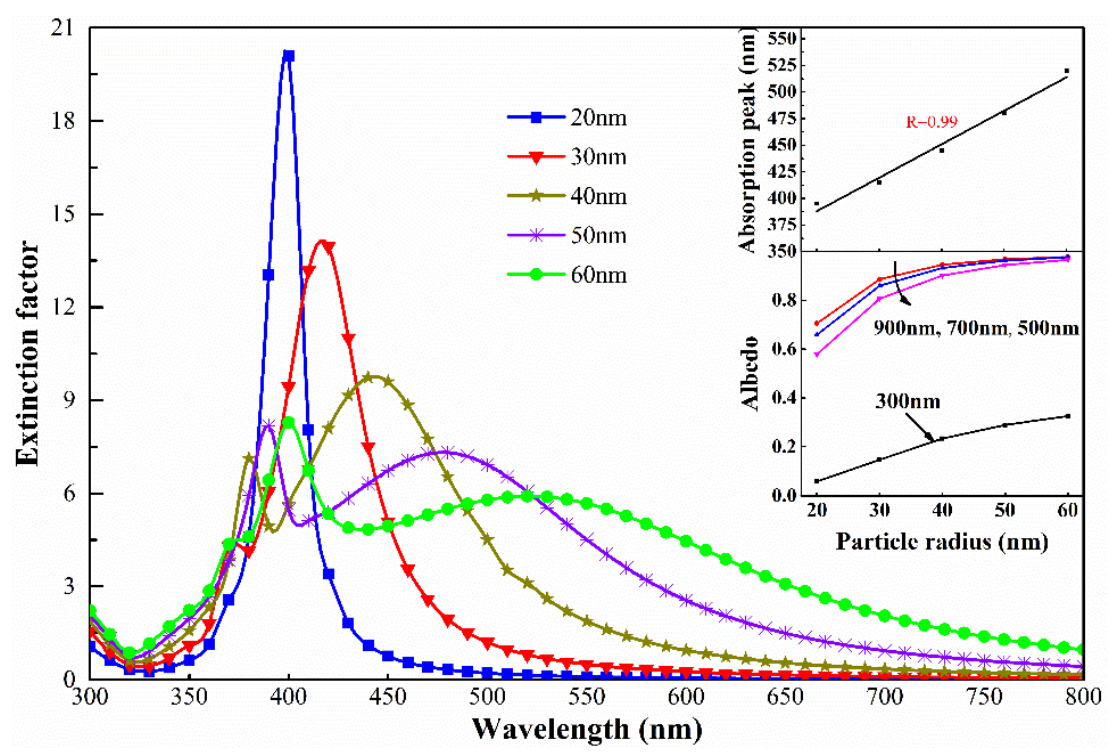

Figure 6: The effect of particle radius on extinction factor of single nanoparticle with refractive index of the environment medium 1.33

For a sphere Ag nanoparticle, its radiative characteristic is determined not only by particle radius, but also by the refractive index of base fluids. The refractive index of environment medium is a direct factor 
affecting the complex refractive index of nanoparticles in the process of radiation transfer. As shown in Figure 7, the extinction factor was less affected by the refractive index of the environment medium, but the absorption peak linearly moved from $360 \mathrm{~nm}$ to $510 \mathrm{~nm}$ when the refractive index of the environment medium increased from 1 to 2, supported by results from reference (Lee and El-Sayed, 2005). The environment medium may change the propagation speed of light, and the incident characteristics on the surface of nanoparticles, affecting the plasma wave inside the metal and making the surface plasmon resonance peak shift. Although increased refractive index of environmental medium would also regulate the spectral absorption range of nanoparticles, the change seemed to be much smaller than that of particle size. Similar to nanoparticles size, the albedo also increased with rising refractive index of base fluids at all wavelength, and followed a nearly linear trend.

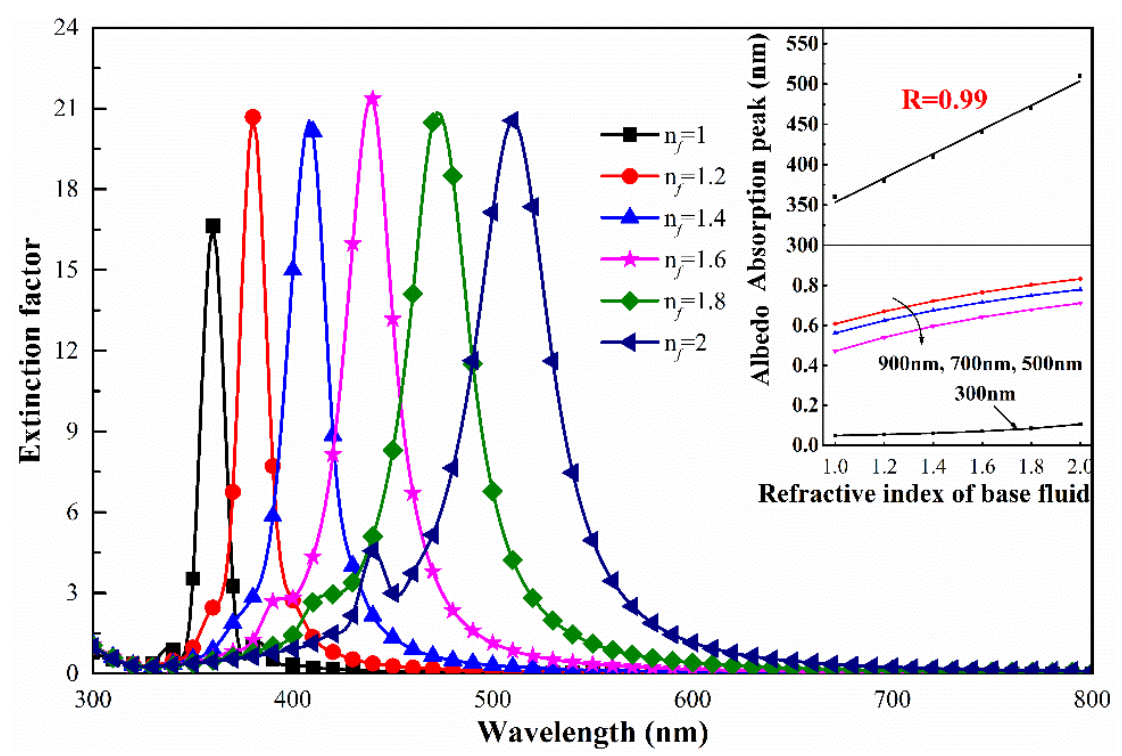

Figure 7: The effect from the refractive index of base fluids on the extinction factor of single nanoparticle for particle radius of $20 \mathrm{~nm}$

\subsection{The effect of environmental parameters on spectral transmittance}

In addition to the effects from nanoparticles' size and refractive index of base fluids, as discussed above, environmental parameters, namely, volume concentration and optical thickness, may also have decisive impact on the spectral transmittance of nanofluids. This section tried to justify this using the 2D-Monte Carlo method developed in this study.

Figure 8 present the effect of the volume concentration on the spectral transmittance, using nanoparticles with the radius of $40 \mathrm{~nm}$. For wavelength between $300 \mathrm{~nm}$ and $900 \mathrm{~nm}$, the changing rule of nanofluids' 
spectral transmittance agreed with the extinction factor of single nanoparticle shown in Figure 6 . When longer than $900 \mathrm{~nm}$, however, the extinction coefficient of basic fluid (water) occupied the dominant role of the extinction coefficient of nanofluids, and the spectral transmittance of nanofluids was equalled to the actually spectral transmittance of water. With increased volume concentration, the spectral transmittance reduced conspicuous, especially around the absorption peak (450nm), due to decreased distance between nanoparticles. There was a high probability that photons were absorbed or scattered by particles when passing through the fluid, leading to the reduced transmittance. For solar cells with ideal windows, Ag-water nanofluids with 1ppm concentration would not be feasible owing to its high spectral transmittance between $300 \mathrm{~nm}$ and $700 \mathrm{~nm}$, resulting in more generated heat and higher cell temperature. Ag-water nanofluids with 5ppm, 7.5ppm and 10ppm, were not suitable either, because of their low spectral transmittance between $700 \mathrm{~nm}$ and $900 \mathrm{~nm}$, resulting in less generated electricity. Through the comparison, Ag-water nanofluids with $2.5 \mathrm{ppm}$ could be the best plan for solar cells, due to its low transmittance between $400 \mathrm{~nm}$ and $600 \mathrm{~nm}$ to achieve low cell temperature, as well as its high transmittance between $700 \mathrm{~nm}$ and $1100 \mathrm{~nm}$ to gain high electricity output.

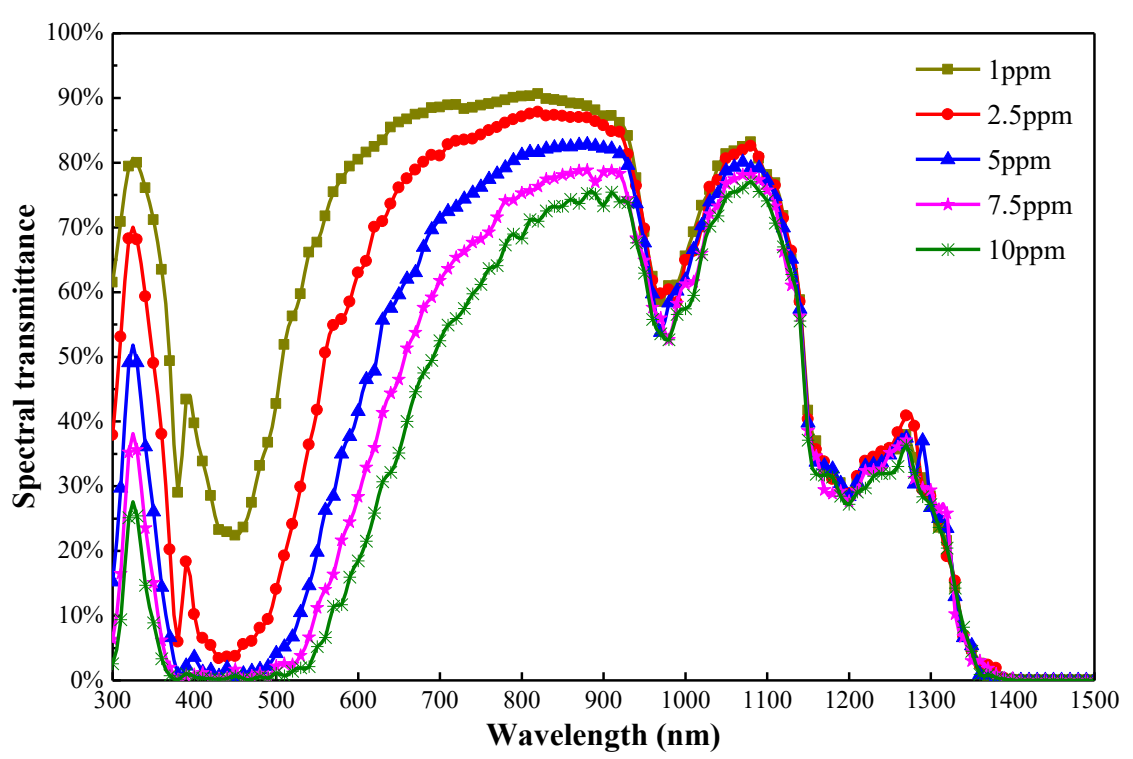

Figure 8: The effect of volume concentration on spectral using nanoparticles with radius of 40nm

As depicted in Figure 9, the spectral transmittance of nanofluids decreased with increased optical thickness, especially for those wavelengths with high extinction coefficient. The Lambert-Beer law indicates that the spectral transmittance of no scattering fluids is negatively correlated with optical thickness, as justified in references (Abdelrazik et al., 2019; Li et al., 2017). For solar cells, higher 
volume concentration of nanofluids was needed for $1 \mathrm{~mm}$ optical thickness, which requires higher investment on nanoparticles. Therefore, for same spectral transmittance, a $10 \mathrm{~mm}$ optical thickness for nanofluids may be suitable for solar cells, due to lower volume concentration for low investment. Since the spectral transmittance was more sensitive to optical thickness, it may be more efficient to adjust optical thickness rather than volume concentration. Of course, the selected optical thickness should be within a reasonable range. Additionally, nanofluids with small volume concentrations will also give reduced agglomeration (Bianco et al., 2015).

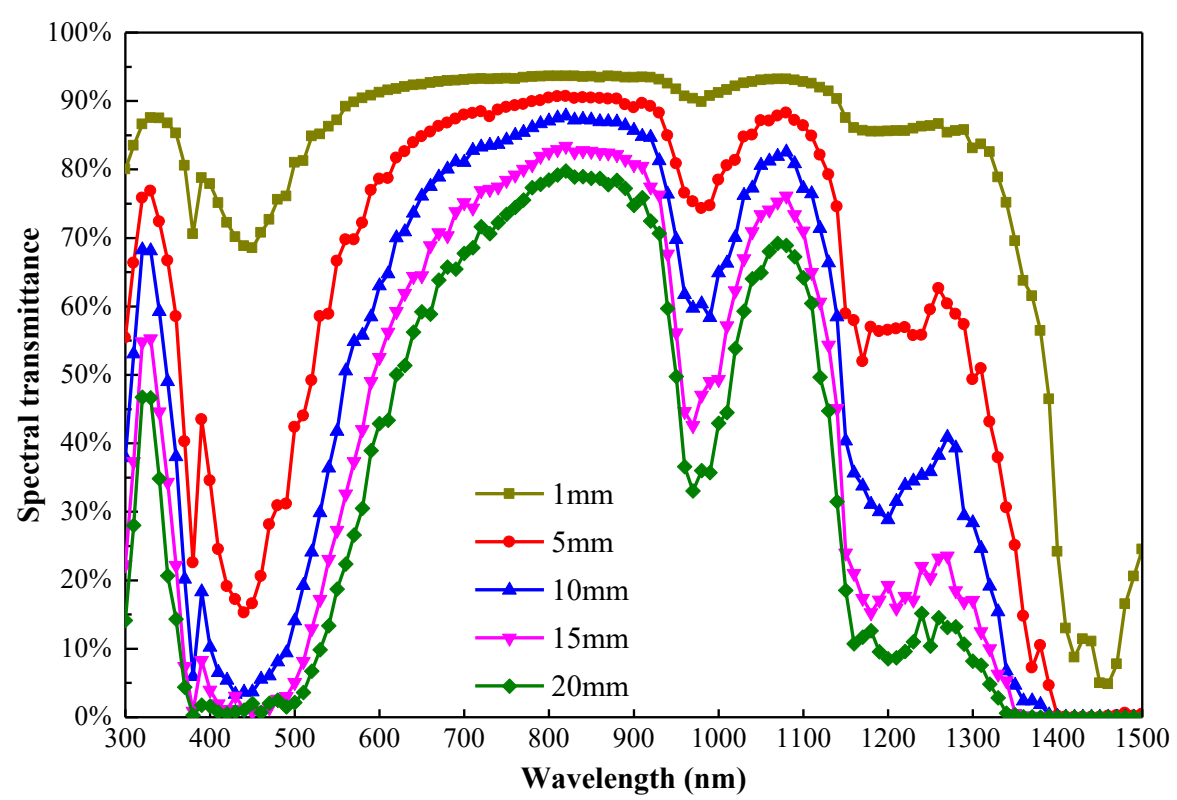

Figure 9: The effect of optical thickness on spectral transmittance using nanoparticles with radius $40 \mathrm{~nm}$

\section{The performance evaluation of PV/T systems}

After discussing the optical regulation characteristics of Ag nanofluids, the performance of PV/T systems with the optimized Ag nanofluids were demonstrated in this section. To perform the demonstration, two mathematical models, including an electrical model and a thermal model, were proposed and validated in Section 5.1 and Section 5.2, respectively.

\subsection{Mathematical models for solar cells}

When nanofluids are used as optical filters for solar cells, two parts of energy need to be considered. One is the electrical energy generated from the cells, and another is the heat energy absorbed by nanofluids.

\subsubsection{Electrical model}

The electrical efficiency $\left(\boldsymbol{\eta}_{\boldsymbol{e l}}\right.$, dimensionless) of solar cells is mainly dependent on short circuit current 
$\left(\boldsymbol{I}_{s c}\right.$, in $\left.\mathrm{mA}\right)$, open circuit voltage $\left(\boldsymbol{V}_{\boldsymbol{o c}}\right.$, in $\left.\mathrm{V}\right)$, fill factor $(\boldsymbol{F F}$, dimensionless $)$ and incident solar radiation $\left(\boldsymbol{G}\right.$, in $\left.\mathrm{W} \cdot \mathrm{m}^{-2} \cdot \mathrm{nm}^{-1}\right)$, as defined by Equation 27 , with fill factor always within 0.7 and 0.83 (Green et al., $2014,2015)$

$$
\eta_{e l}=\frac{I_{s c} V_{o c} F F}{G}
$$

The short circuit current is generated by incident solar radiation, spectral transmittance $\left(\boldsymbol{\tau}_{\lambda}\right.$, dimensionless) and spectral response (SR, A $\left.\cdot \mathrm{W}^{-1}\right)($ Hjerrild et al., 2016), while the open circuit voltage is affected by short circuit current, dark saturation current $\left(\boldsymbol{I}_{\boldsymbol{o}}\right.$, in $\left.\mathrm{mA}\right)$ and cell temperature $\left(\boldsymbol{T}_{\text {cell }}\right.$, in $\left.{ }^{\circ} \mathrm{C}\right)$, as depicted with Equations 28 and 29.

$$
\begin{gathered}
I_{s c}=\int_{300}^{4000} G(\lambda) \tau_{\lambda}(\lambda) \operatorname{SR}(\lambda) d \lambda \\
V_{o c}=\frac{A^{\prime} k_{b} T_{c e l l}}{e} \ln \left(\frac{I_{s c}}{I_{0}}+1\right)
\end{gathered}
$$

where $\boldsymbol{A}^{\prime}$ is 0.99 for Si cells and 1.1 for GaAs cells (Hassani et al., 2016), $\boldsymbol{K}_{\boldsymbol{b}}$ is Boltzmann constant, $1.38 \times 10^{-23} \mathrm{~J} / \mathrm{K}, \boldsymbol{e}$ is electron charge, $1.6021 \times 10^{-19} \mathrm{C}$, and $\boldsymbol{C}$ is solar concentration ratio.

Equation 30 can be used to evaluate open circuit voltage when cell temperature is higher than $25^{\circ} \mathrm{C}$ (Fudholi et al., 2014). The dark saturation current can be obtained by Equation 32,

$$
\begin{gathered}
V_{o c}=V_{o c}{ }^{\prime}\left(1-\beta\left(T_{\text {cell }}-T_{\text {cell }}{ }^{\prime}\right)\right) \\
V_{o c}=\frac{A^{\prime} k_{b} T_{\text {cell }}}{e} \ln \left(\frac{C I_{\text {sc }}}{I_{0}}+1\right) \\
I_{0}=K^{\prime} T_{\text {cell }}^{3 / n} \exp \left(\frac{-E_{g}}{m k_{b} T_{\text {cell }}}\right)
\end{gathered}
$$

where $\boldsymbol{T}_{\text {cell }}^{\prime}$ is $25^{\circ} \mathrm{C}, \boldsymbol{V}_{\boldsymbol{o c}}^{\prime}$ is open circuit voltage at $25^{\circ} \mathrm{C}, \boldsymbol{\beta}$ is $0.0045 \mathrm{~K}^{-1}, \boldsymbol{K}, \boldsymbol{m}$ and $\boldsymbol{n}$ are empirical constants available in reference (Fan, 1986). The fill factor can be calculated by Equation 33, with $\boldsymbol{V}_{\boldsymbol{m}}$ as the voltage at the maximum power point (in V) and $\boldsymbol{k}$ within 0.7 and 0.8 (Hassani et al., 2016).

$$
F F=\frac{V_{m}}{V_{o c}}\left[1-\frac{\exp \left(\frac{e V_{m}}{k_{b} T_{\text {cell }}}\right)-1}{\exp \left(\frac{e V_{o c}}{k_{b} T_{\text {cell }}}\right)-1}\right]
$$




\subsubsection{Thermal model}

When solar radiation passes through nanofluids and arrives on the surface of solar cells, the total energy could be divided into three parts: 1) energy absorbed by nanofluids due to extinction effect; 2) energy converted into electricity by solar cells, and 3) energy heating solar cells. For a PV/T system, the overall thermal efficiency $\left(\boldsymbol{\eta}_{\boldsymbol{t h}}\right)$ can be defined as the ratio of the first part energy to the incident solar radiation, as defined by Equation 35. However, due to Fresnel losses and absorption of optical glasses, the overall thermal efficiency can only be up to $67 \%$ of the theoretical value $\left(\boldsymbol{\eta}_{\boldsymbol{t h}}\right)$ (Han et al., 2019b).

$$
\eta_{t h}=\frac{\int_{280}^{4000} G(\lambda)\left(1-\tau_{\lambda}(\lambda)\right) d \lambda}{G}
$$

When PV/T systems reach steady-state condition, the third part of energy keeps balance, meaning that the energy obtained from sun is equals to the heat loss to the ambient environment. This part of heat is consisted of convection heat loss and radiation heat loss, with convection heat loss calculated by Equation 36 and radiation heat loss calculated by Stefan-Boltzmann law (Equation 37),

$$
\begin{gathered}
Q_{h}=h A\left(T_{\text {cell }}-T_{a}\right) \\
Q_{r}=\varepsilon \sigma\left(T_{\text {cell }}{ }^{4}-T_{\text {sky }}{ }^{4}\right)
\end{gathered}
$$

where $\boldsymbol{T}_{\text {cell }}, \boldsymbol{T}_{\boldsymbol{a}}$ and $\boldsymbol{T}_{\text {sky }}$ are sky temperature, ambient temperature and cell temperature (K), $\boldsymbol{h}$ is convective heat transfer coefficient (in $\left.\mathrm{W} /\left(\mathrm{m}^{2} \cdot \mathrm{K}\right)\right), \boldsymbol{A}$ is heat transfer area (in $\left.\mathrm{m}^{2}\right), \boldsymbol{\varepsilon}$ is surface emissivity of object (dimensionless), and $\boldsymbol{\sigma}$ is the Boltzmann constant $\left(5.67 \times 10^{-8} \mathrm{~W} \cdot \mathrm{m}^{-2} \cdot \mathrm{K}^{-4}\right)$ (Siegel and Howell, 2002).

\subsection{Validating the electrical model and the thermal model}

Before investigating the performance of PV/T systems with nanofluids, the accuracy of both mathematical models developed in Section 5.1, needed to be validated with reference (Han et al., 2019b). Under standard test conditions (with cell temperature of $25^{\circ} \mathrm{C}$, solar radiation of $1000 \mathrm{~W} / \mathrm{m}^{2}$ at $\mathrm{AM} 1.5$, effective area of Si cell of $2 \mathrm{~cm} \times 2 \mathrm{~cm}$ ), short circuit current and open circuit voltage calculated by mathematical models were $126.6 \mathrm{~mA}$ and $0.62 \mathrm{~V}$, while these given by manufacturer were $134 \mathrm{~mA}$ and 0.6V, respectively (Han et al., 2019b). Table 1 listed both calculated values and tested values, and a good match was observed, with calculation errors less than $0.7 \%$.

Table 1 Comparison between calculated value and experimental value (Han et al., 2019b) 


\begin{tabular}{lccccc}
\hline \multirow{2}{*}{ Solar cells } & \multicolumn{2}{c}{ Short circuit current $\left(\boldsymbol{I}_{\boldsymbol{s c}}\right)$} & & \multicolumn{2}{c}{ Electrical efficiency $\left(\boldsymbol{\eta}_{\boldsymbol{l} l}\right)$} \\
\cline { 2 - 3 } & Tested & Calculated & & Tested & Calculated \\
\hline Si cell only & 32.2 & 31.65 & & $15.7 \%$ & $15.64 \%$ \\
Si cell with water above & 31.1 & 29.77 & & $15.2 \%$ & $14.68 \%$ \\
GaAs cell only & 15.5 & 15.34 & & $12.0 \%$ & $11.41 \%$ \\
GaAs cell with water above & 15.1 & 15.03 & & $10.5 \%$ & $11.17 \%$ \\
\hline
\end{tabular}

432

433

\subsection{Performance of PV/T systems with optimal nanofluids}

When the nanofluid is located on the top of solar cells, it will inevitably reduce electrical efficiency and boost thermal efficiency of solar cell. To sufficiently evaluate the performance of a whole PV/T system, the ratio of electricity to thermal energy was assumed as 3, according to reference (Han et al., 2019b). Therefore, the merit function of solar cells is defined by Equation 38 .

$$
M F=\frac{w \cdot P_{e l}+P_{t h}}{w \cdot P_{e l}(\text { solar cell only })}
$$

In this study, eight scenarios have been tested in terms of the performance of PV/T systems, as defined in Table 2, with volume concentration of $2.5 \mathrm{ppm}$ and optical thickness of $10 \mathrm{~mm}$.

Table 2: Eight scenarios to investigate the performance of solar cells with and without nanofluids

\begin{tabular}{ccccc}
\hline No. & Nanoparticles & Base fluid & Volume concentration & Optical thickness \\
\hline 1 & -- & -- & -- & -- \\
2 & -- & Water & -- & $10 \mathrm{~mm}$ \\
3 & Ag $20 \mathrm{~nm}$ & Water & $2.5 \mathrm{ppm}$ & $10 \mathrm{~mm}$ \\
4 & $\operatorname{Ag~} 40 \mathrm{~nm}$ & Water & $2.5 \mathrm{ppm}$ & $10 \mathrm{~mm}$ \\
5 & $\operatorname{Ag~} 50 \mathrm{~nm}$ & Water & $2.5 \mathrm{ppm}$ & $10 \mathrm{~mm}$ \\
6 & $\operatorname{Ag}(20 \mathrm{~nm}+40 \mathrm{~nm}, 8: 2)$ & Water & $2.5 \mathrm{ppm}$ & $10 \mathrm{~mm}$ \\
7 & $\operatorname{Ag}(20 \mathrm{~nm}+40 \mathrm{~nm}, 5: 5)$ & Water & $2.5 \mathrm{ppm}$ & $10 \mathrm{~mm}$ \\
8 & $\operatorname{Ag}(20 \mathrm{~nm}+40 \mathrm{~nm}, 2: 8)$ & Water & $2.5 \mathrm{ppm}$ & $10 \mathrm{~mm}$ \\
\hline
\end{tabular}


The short circuit current, electrical efficiency and cell temperature of the Si cell and the GaAs cell for different nanofluids at steady state (convective heat transfer coefficient is $15 \mathrm{~W} /\left(\mathrm{m}^{2} \cdot \mathrm{K}\right)$ ) were depicted as Figure 10. Existing literature (Duffie and Beckman, 2013) has already proven that the short circuit current of solar cells has a linear relationship with the incident solar radiation, but no relationship with the cell temperature. If the nanofluid is placed on the surface of solar cells, some energy will be absorbed by nanofluids depending on the spectral transmittance, and then the incident solar radiation on solar cells will be reduced, resulting in smaller short circuit current. However, increased cell temperature had a negative influence on the open circuit voltage, and then affected the electrical efficiency of solar cells. The cell temperature of solar cells without filters (Scenario 1) increased by $38.8^{\circ} \mathrm{C}$ for the Si cell and $40.3^{\circ} \mathrm{C}$ for the GaAs cell, and electrical efficiency decreased by $3 \%$ for Si cell and $2.11 \%$ for GaAs cell, and this result was supported by reference (Al-Waeli et al., 2018). Therefore, the issue of lower electrical efficiency caused by high cell temperature must be considered seriously (Zhang et al., 2020a).
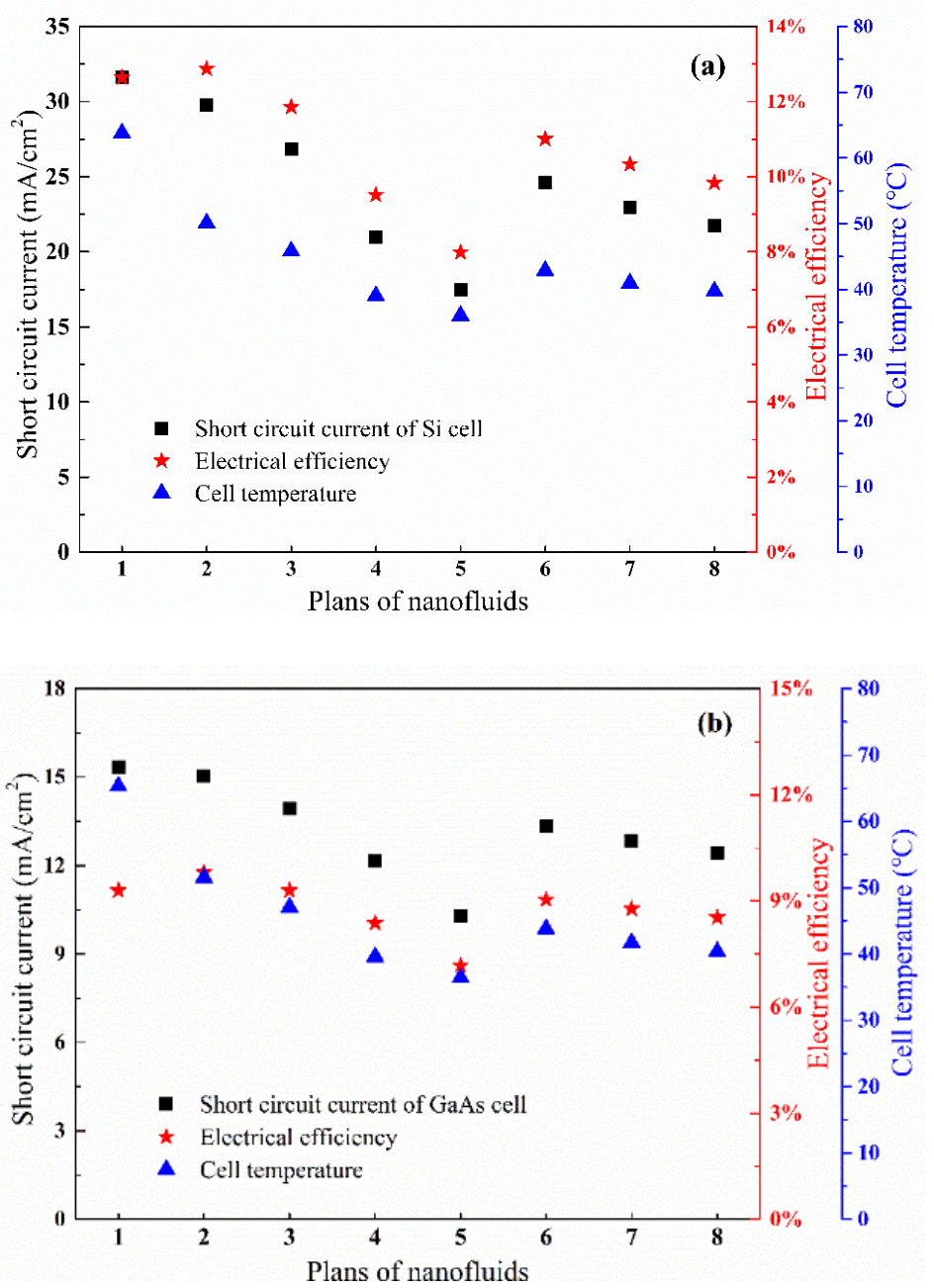

Figure 10: Short circuit current, electrical efficiency and cell temperature of Si cell (a) and GaAs cell (b) 
As described in Section 4.1, the Ag/water nanofluid with radius of 50nm was not a suitable optical filter,

due to its large absorption range, resulting in reduced spectral transmittance in the visible region and decreased incident solar radiation on the surface of solar cells. The short circuit current and electrical efficiency were $17.47 \mathrm{~mA} / \mathrm{cm}^{2}$ and $7.99 \%$ for the Si cell, and $10.29 \mathrm{~mA} / \mathrm{cm}^{2}$ and $7.17 \%$ for the GaAs cell. Due to the different spectral response ranges of the Si cell and the GaAs cell, their ranges of directional regulation were different as well (Han et al., 2019b). Although the ideal PV window for silicon cells is $700 \mathrm{~nm}$ to $1100 \mathrm{~nm}$, the spectral response between $500 \mathrm{~nm}$ and $700 \mathrm{~nm}$ is still high. Owing to higher extinction factor, the absorbing ability of $\mathrm{Ag} /$ water nanofluids with radius of 40nm, was higher than that with radius of $20 \mathrm{~nm}$ during the spectrum of $500 \mathrm{~nm}-700 \mathrm{~nm}$, resulting in less solar energy to response and reduced electrical efficiency.

In contrast, due to the small spectral response range of the GaAs cell, only the directional transmission for spectral energy of 700nm-900nm was required to achieve efficient operation of solar cell (Han et al., 2019b). Even so, an Ag/water nanofluid with radius of 40nm still decreases electrical efficiency, but with smaller range. Detailedly, the electrical efficiency of Si cell was $11.85 \%$ for $20 \mathrm{~nm} \mathrm{Ag} /$ water nanofluids and $9.52 \%$ for $40 \mathrm{~nm} \mathrm{Ag} /$ water nanofluids. For the GaAs cell, it was $9.30 \%$ for $20 \mathrm{~nm} \mathrm{Ag} /$ water nanofluids and $8.37 \%$ for $40 \mathrm{~nm} \mathrm{Ag/water} \mathrm{nanofluids,} \mathrm{respectively.} \mathrm{Scenarios} 6,7$ and 8 were blended nanofluids mixed with 20nm and 40nm Ag nanoparticles, and these performances of PV/T systems were located between the performance of Scenario 3 and Scenario 4. In general, 20nm Ag/water nanofluids was a positive solution for both Si cells and GaAs cells to achieve better electrical efficiency.

After the active absorption by nanofluids, the recycle of waste heat should be considered. The spectral directional absorption of nanofluids will play a positive role to evaluate the performance of PV/T systems, and the heat would boost the overall efficiency of PV/T systems. As shown in Figure 11, the solution with $50 \mathrm{~nm} \mathrm{Ag/water} \mathrm{nanofluids} \mathrm{gave} \mathrm{the} \mathrm{highest} \mathrm{thermal} \mathrm{efficiency} \mathrm{for} \mathrm{both} \mathrm{the} \mathrm{Si} \mathrm{cell} \mathrm{and} \mathrm{the} \mathrm{GaAs}$ cell, due to higher spectral absorption in the visible region. However, electrical efficiency with $50 \mathrm{~nm}$ $\mathrm{Ag} /$ water nanofluids was the lowest, and corresponding MF value was the lowest with considering worth factor (Higher quality energy for electricity). Consistent with the above analysis, 20nm or 20/40nm (8:2) $\mathrm{Ag} /$ water nanofluids were optimal solutions for both the Si cell and the GaAs cell as well, with MF values of 1.61, 1.66 for the Si cell and 1.92, 2.05 for the GaAs cell, respectively. It should be noted that solar cells with pure water, i.e. no nanofluids, showed excellent performance, owing to complete absorption 
by water in infrared region (no less than 1400nm) and almost complete transmission in UV-visible band, but with low MF values. References have also reported that there was lower electricity yield for PV/T systems with nanofluids than that with pure water (Crisostomo et al., 2015), and PV modules only was regarded as highest electrical efficiency (Hjerrild et al., 2016). Different nanofluid solutions can meet various user needs. That is, if the demand for electric power was small, $50 \mathrm{~nm} \mathrm{Ag} \mathrm{nanofluids} \mathrm{can} \mathrm{be} \mathrm{used;}$ if the demand for electric power was high, pure water or $20 \mathrm{~nm} \mathrm{Ag} \mathrm{nanofluids} \mathrm{can} \mathrm{be} \mathrm{used} \mathrm{directly.}$
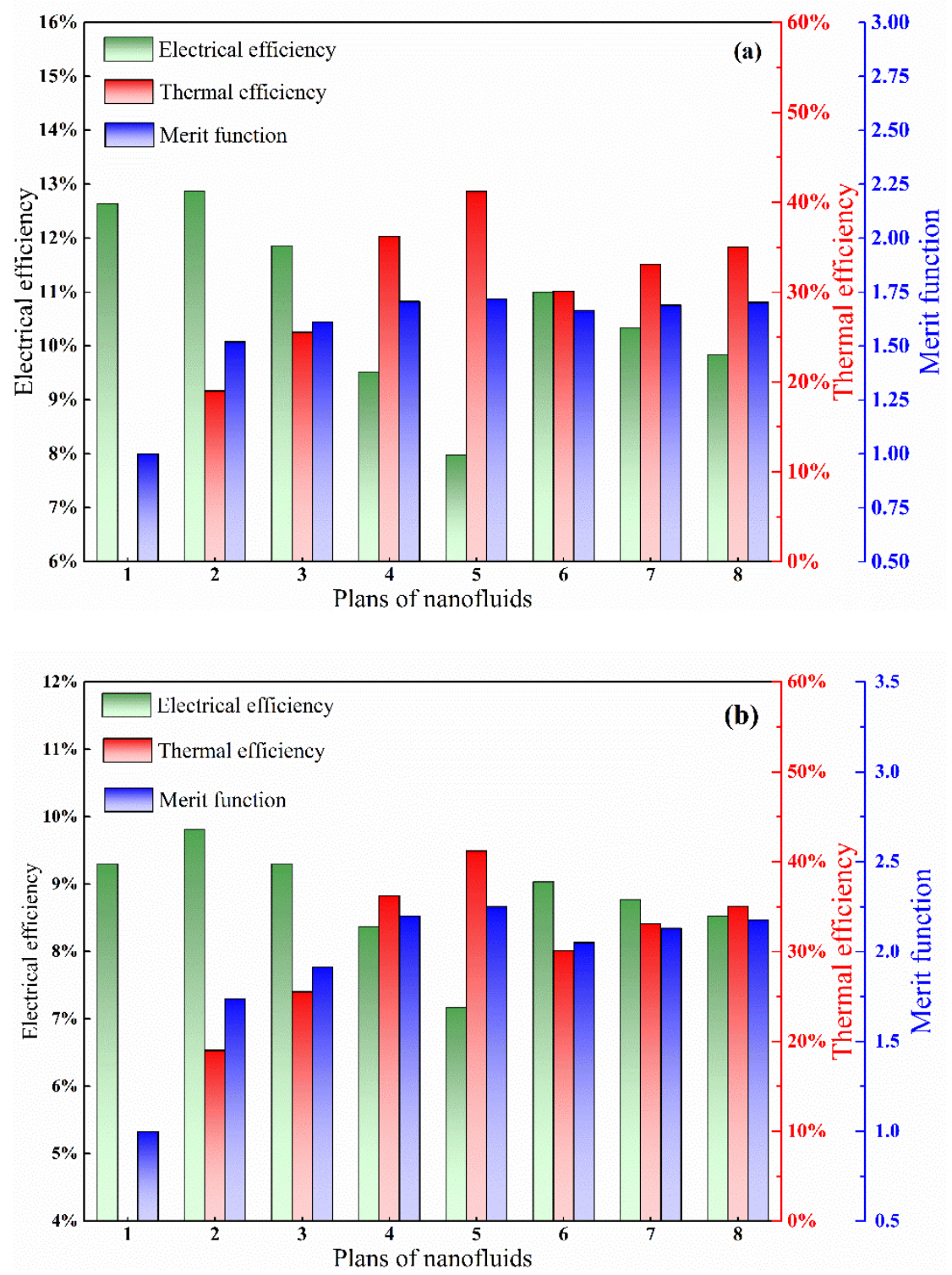

Figure 11: Merit function, energy conversion efficiency of Si cell (a) and GaAs cell (b) for different nanofluids at steady state

\section{Conclusion}

The energy not match solar cells, will not generate electric energy, but will form thermal accumulation 
on the surface of PV modules, thus reducing electrical efficiency. To realize directional absorption of energy not responding to solar cells and boost the overall efficiency of PV/T systems, optical regulating characteristic of $\mathrm{Ag}$ nanofluids were investigated using a 2D-Monte Carlo method. Meanwhile, the output performance of PV/T systems with optimal Ag nanofluids were discussed. Main conclusions from this study were listed as followings:

A 2D-Monte Carlo method was developed and validated to estimate spectral transmittance of nanofluids, with an average relative error less than $3.92 \%$ for different mass fractions. When the radius of $\mathrm{Ag}$ spherical nanoparticles increased from $20 \mathrm{~nm}$ to $60 \mathrm{~nm}$, the absorption peak of nanoparticles showed a linear shift from $395 \mathrm{~nm}$ to $520 \mathrm{~nm}$, and the effect of the refractive index was similar to that of particle radius.

Both volume concentration and optical thickness of nanofluids were negative factors to the spectral transmittance, leading to lower electrical efficiency but higher thermal efficiency. Ag nanofluids, with particle radius of $20 \mathrm{~nm}$ or $20 / 40 \mathrm{~nm}(8: 2)$, volume concentration of $2.5 \mathrm{ppm}$ and optical path of $10 \mathrm{~mm}$, were optimal solutions for both Si cells and GaAs cells, with electrical efficiencies and MF values of $11.85 \%$ and $1.61,11.0 \%$ and 1.66 for Si cells, and $9.30 \%$ and $1.92,9.03 \%$ and 2.05 for GaAs cells, respectively.

\section{Acknowledgement}

The authors gratefully acknowledge the funding support from State Key Lab of Subtropical Building Science, South China University of Technology (No. 2020ZB15).

\section{References}

Abdelrazik, A.S., Al-Sulaiman, F.A., Saidur, R., 2019. Optical behavior of a water/silver nanofluid and their influence on the performance of a photovoltaic-thermal collector. Solar Energy Materials and Solar Cells 201, 110054.

Al-Waeli, A.H.A., Sopian, K., Kazem, H.A., Yousif, J.H., Chaichan, M.T., Ibrahim, A., Mat, S., Ruslan, M.H., 2018. Comparison of prediction methods of PV/T nanofluid and nano-PCM system using a measured dataset and artificial neural network. Solar Energy 162, 378-396.

Ali, H.M., 2020. Recent advancements in PV cooling and efficiency enhancement integrating phase change materials based systems - A comprehensive review. Solar Energy 197, 163-198.

Bianco, V., Manca, O., Nardini, S., Vafai, K., 2015. Heat Transfer Enhancement With Nanofluids (chapter 1). Taylor \& Francis

Cheng, Q., Chai, J., Zhang, Z., 2016. Investigation of double-layer coating pigmented with $\mathrm{CuO}$ particles of different concentrations on aesthetic and thermal aspects. International Journal of Thermal Sciences 
$105,36-44$.

530 Crisostomo, F., Taylor, R.A., Surjadi, D., Mojiri, A., Rosengarten, G., Hawkes, E.R., 2015. Spectral splitting strategy and optical model for the development of a concentrating hybrid PV/T collector. Applied Energy 141, 238-246. DeJarnette, D., Tunkara, E., Brekke, N., Otanicar, T., Roberts, K., Gao, B., Saunders, A.E., 2016. Nanoparticle enhanced spectral filtration of insolation from trough concentrators. Solar Energy Materials and Solar Cells 149, 145-153.

Duffie, J.A., Beckman, W.A., 2013. Solar Engineering of Thermal Processes, Fourth Edition (Chapter 23). Wiley Fan, J.C.C., 1986. Theoretical temperature dependence of solar cell parameters. Solar Cells 17(2), 309315.

Félidj, N., Grand, J., Laurent, G., Aubard, J., Lévi, G., Hohenau, A., Galler, N., Aussenegg, F.R., Krenn, J.R., 2008. Multipolar surface plasmon peaks on gold nanotriangles. The Journal of Chemical Physics 128(9), 094702.

Fudholi, A., Sopian, K., Yazdi, M.H., Ruslan, M.H., Ibrahim, A., Kazem, H.A., 2014. Performance analysis of photovoltaic thermal (PVT) water collectors. Energy Conversion and Management 78, 641651.

Ghosh, A., Sarmah, N., Sundaram, S., Mallick, T.K., 2019. Numerical studies of thermal comfort for semi-transparent building integrated photovoltaic (BIPV)-vacuum glazing system. Solar Energy 190, 608-616.

Green, M.A., Emery, K., Hishikawa, Y., Warta, W., Dunlop, E.D., 2014. Solar cell efficiency tables (version 44). Progress in Photovoltaics: Research and Applications 22(7), 701-710.

Green, M.A., Emery, K., Hishikawa, Y., Warta, W., Dunlop, E.D., 2015. Solar cell efficiency tables (Version 45). Progress in Photovoltaics: Research and Applications 23(1), 1-9.

Han, X., Chen, X., Wang, Q., Alelyani, S.M., Qu, J., 2019a. Investigation of CoSO4-based Ag nanofluids as spectral beam splitters for hybrid PV/T applications. Solar Energy 177, 387-394. Han, X., Xue, D., Zheng, J., Alelyani, S.M., Chen, X., 2019b. Spectral characterization of spectrally selective liquid absorption filters and exploring their effects on concentrator solar cells. Renewable Energy 131, 938-945. Hasan, A., McCormack, S.J., Huang, M.J., Norton, B., 2010. Evaluation of phase change materials for thermal regulation enhancement of building integrated photovoltaics. Solar Energy 84(9), 1601-1612. Hassani, S., Taylor, R.A., Mekhilef, S., Saidur, R., 2016. A cascade nanofluid-based PV/T system with optimized optical and thermal properties. Energy 112, 963-975. investigation of sintered nanoparticles. Journal of Quantitative Spectroscopy and Radiative Transfer 123, 53-61. enhancement using selectively absorbing Ag-SiO2/carbon nanofluids. Solar Energy Materials and Solar Cells 147, 281-287.

568 Hjerrild, N.E., Taylor, R.A., 2017. Boosting solar energy conversion with nanofluids. Physics Today $56970(12), 40-45$.

570 Jain, P.K., Lee, K.S., El-Sayed, I.H., El-Sayed, M.A., 2006. Calculated Absorption and Scattering 571 Properties of Gold Nanoparticles of Different Size, Shape, and Composition: Applications in Biological 
Lee, K.-S., El-Sayed, M.A., 2005. Dependence of the Enhanced Optical Scattering Efficiency Relative to That of Absorption for Gold Metal Nanorods on Aspect Ratio, Size, End-Cap Shape, and Medium Refractive Index. The Journal of Physical Chemistry B 109(43), 20331-20338.

Li, D., Wu, Y., Liu, C., Zhang, X., Qi, H., Jiang, M., 2017. Comparison between transmittance equations of optical cell for calculating optical constants of liquid materials. Optik 130, 1197-1204.

McPeak, K.M., Jayanti, S.V., Kress, S.J.P., Meyer, S., Iotti, S., Rossinelli, A., Norris, D.J., 2015. Plasmonic Films Can Easily Be Better: Rules and Recipes. ACS Photonics 2(3), 326-333.

Menni, Y., Azzi, A., Chamkha, A.J., 2018. A Review of Solar Energy Collectors: Models and Applications. Journal of Applied and Computational Mechanics 4(4), 375-401.

Menni, Y., Azzi, A., Chamkha, A.J., 2019a. Computational thermal analysis of turbulent forcedconvection flow in an air channel with a flat rectangular fin and downstream v-shaped baffle. Heat Transfer Research 50(18), 1781-1818.

Menni, Y., Chamkha, A.J., Ameur, H., 2020. Advances of nanofluids in heat exchangers-A review. Heat Transfer $\mathrm{n} / \mathrm{a}(\mathrm{n} / \mathrm{a})$.

Menni, Y., Chamkha, A.J., Azzi, A., 2019b. Nanofluid Flow in Complex Geometries - A Review. Journal of Nanofluids 8(5), 893-916.

Muneeshwaran, M., Sajjad, U., Ahmed, T., Amer, M., Ali, H.M., Wang, C.-C., 2020. Performance improvement of photovoltaic modules via temperature homogeneity improvement. Energy 203, 117816. Ren, Y., Qi, H., Chen, Q., Wang, S., Ruan, L., 2017. Localized surface plasmon resonance of nanotriangle dimers at different relative positions. Journal of Quantitative Spectroscopy and Radiative Transfer 199, 45-51.

Sahin, A.Z., Uddin, M.A., Yilbas, B.S., Al-Sharafi, A., 2020. Performance enhancement of solar energy systems using nanofluids: An updated review. Renewable Energy 145, 1126-1148.

Shen, C., Lv, G., Wei, S., Zhang, C., Ruan, C., 2020. Investigating the performance of a novel solar lighting/heating system using spectrum-sensitive nanofluids. Applied Energy 270, 115208.

Siegel, R., Howell, J., 2002. Thermal Radiation Heat Transfer. McGraw-Hill.

Tan, J., Xie, Y., Wang, F., Jing, L., Ma, L., 2017. Investigation of optical properties and radiative transfer of $\mathrm{TiO} 2$ nanofluids with the consideration of scattering effects. International Journal of Heat and Mass Transfer 115, 1103-1112.

Tariq, S.L., Ali, H.M., Akram, M.A., Janjua, M.M., Ahmadlouydarab, M., 2020. Nanoparticles enhanced phase change materials (NePCMs)-A recent review. Applied Thermal Engineering 176, 115305.

Taylor, R.A., Otanicar, T., Rosengarten, G., 2012. Nanofluid-based optical filter optimization for PV/T systems. Light: Science \& Applications 1(10), e34-e34.

Wei, W., Ni, L., Xu, L., Yang, Y., Yao, Y., 2020. Application characteristics of variable refrigerant flow heat pump system with vapor injection in severe cold region. Energy and Buildings 211, 109798.

Wriedt, T., 2009. Light scattering theories and computer codes. Journal of Quantitative Spectroscopy and Radiative Transfer 110(11), 833-843.

Xingcai, L., Kun, N., 2018. Effectively predict the solar radiation transmittance of dusty photovoltaic panels through Lambert-Beer law. Renewable Energy 123, 634-638.

Yao, J., Chen, E., Dai, Y., Huang, M., 2020. Theoretical analysis on efficiency factor of direct expansion PVT module for heat pump application. Solar Energy 206, 677-694.

Yi, H.-L., Wang, C.-H., Tan, H.-P., 2014. Transient radiative transfer in a complex refracting medium by a modified Monte Carlo simulation. International Journal of Heat and Mass Transfer 79, 437-449.

Younes Menni, Ali J. Chamkha, Chafika Zidani, Benyoucef, B., 2019a. Heat and nanofluid transfer in 
617 baffled channels of different outlet models. Mathematical Modelling of Engineering Problems 6(1), 21-

61828

619 Younes Menni, Ali J. Chamkha, Giulio Lorenzini, Noureddine Kaid, Houari Ameur, Bensafi, M., $2019 \mathrm{~b}$.

620 Advances of Nanofluids in Solar Collectors - A Review of Numerical Studies. Mathematical Modelling 621 of Engineering Problems 6(3), 415-427.

622 Zhang, c., Shen, c., Wei, S., Wang, Y., Lv, G., Sun, C., 2020a. A review on recent development of cooling 623 technologies for photovoltaic modules. Journal of thermal science, DOI: https://doi.org/10.1007/s11630624 020-1350-y.

625 Zhang, C., Shen, C., Yang, Q., Wei, S., Lv, G., Sun, C., 2020b. An investigation on the attenuation effect 626 of air pollution on regional solar radiation. Renewable Energy DOI: https://doi.org/10.1016/j.renene. $627 \quad 2020.07 .146$.

628 Zhang, X., Yang, Y., Zhang, J., Li, R., 2019. Scattering of an Airy light-sheet by a non-spherical particle 629 using discrete dipole approximation. Journal of Quantitative Spectroscopy and Radiative Transfer 225, $630 \quad 84-90$.

631 Zhu, Q., Cui, Y., Mu, L., Tang, L., 2013. Characterization of Thermal Radiative Properties of Nanofluids 632 for Selective Absorption of Solar Radiation. International Journal of Thermophysics 34(12), 2307-2321. 